\title{
Malignant Ovarian Granulosa Cell Tumor
}

National Cancer Institute

\section{Source}

National Cancer Institute. Malignant Ovarian Granulosa Cell Tumor. NCI Thesaurus. Code C8403.

An aggressive granulosa cell tumor that arises from the ovary and metastasizes to other anatomic sites. 